\title{
Hyponatraemia Syndrome in Acute Myeloid Leukaemia
}

\author{
M. A. MIR, I. W. DELAMORE
}

British Medical fournal, 1974, 1, 52-55

\section{Summary}

Hyponatraemia was observed in 11 out of 14 consecutive patients with acute myeloid leukaemia and its variants. Metabolic studies on these patients revealed an early increase in the urinary sodium excretion, negative free water clearance, and urine osmolality inappropriately higher than that of the serum. It is postulated that this syndrome is caused by a substance released from the primitive cells of the abnormal myeloid series.

\section{Introduction}

A state of low serum sodium had been seen to occur frequently during the course of their illness in patients with acute myeloid leukaemia and its variants. This paper presents pertinent data on 14 patients together with balance studies on two of these in whom hyponatraemia developed as the result of unexplained sodium wasting from the kidney.

\section{Patients and Methods}

To investigate the electrolyte disturbances often seen in association with acute leukaemia, $\mathrm{Na}$ and $\mathrm{K}$ balance studies were conducted on all newly-admitted patients with acute myeloid leukaemia These studies were generally limited to a five-day period covering each admission and readmission to hospital. This study concerns 14 consecutive patients who were investigated in this manner. Two of these (cases 2 and 4, see below) were investigated intensively throughout the period of their stay in hospital. The effects of saline and fluid loads were studied in these two patients (figs. 1 and 2). The values of dietary $\mathrm{Na}, \mathrm{K}$, and nitrogen were calculated by the method of McCance and Widdowson (1969). Food eaten was accounted for in the final analysis of these values.

Twenty-four-hour urine collections beginning at 8 a.m. each day were made, using chloroform as preservative. Blood samples were obtained and analysed on the same day. Body weight was measured after voiding. The measurements of $\mathrm{Na}$ and $\mathrm{K}$ were carried out with a flame photometer and those of urea and chloride in a Technicon AutoAnalyzer. Osmolality of serum and urine was determined by advanced osmometer. However, in case 4 on days $1,2,5$, and 12 (fig. 2) osmolality of urine was estimated indirectly-that is $2(\mathrm{Na}+\mathrm{K})+$ Urea $\mathrm{mg} / \mathrm{l}$.

\section{Mol. Wt. of urea $(=60)$}

Plasma cortisol was determined fluorometrically (Mattingly et al., 1964) and serum thyroxine by the T-4 column test (Biorad Co.). Plasma arginine vasopressin was determined by radioimmunoassay (Beardwell, 1971). Other investigations were performed by standard laboratory methods.

\footnotetext{
University Department of Clinical Haematology, Manchester Royal Infirmary, Manchester M13 9WL

M. A. MIR, M.B., M.R.C.P., Registrar

I. W. DELAMORE, M.R.C.PATH., F.R.C.P., Physician-in-charge
}

\section{Case Reports}

Case 2.-A 58-year-old woman was admitted to hospital from the casualty department which she had been attending for treatment of an ulcer on her right thigh. A routine blood count had shown a haemoglobin level of $9.1 \mathrm{~g} / 100 \mathrm{ml}$, platelets $91,000 / \mathrm{mm}^{3}$, and a white cell count of $2,800 / \mathrm{mm}^{3}$ with $15 \%$ blast cells. On examination she was febrile and found to have moderate hepatosplenomegaly. A bone marrow aspiration showed a highly cellular specimen with myeloblasts accounting for $95 \%$ of the cells. Initial laboratory investigations showed blood urea, serum electrolytes, plasma proteins, hepatic function tests, immunoglobulins, and urine analysis to be within normal limits. A diagnosis of acute myeloid leukaemia was made and the patient was admitted to the sixth M.R.C. trial. On the third day in hospital induction therapy, consisting of a single intravenous administration of daunorubicin $(1.5 \mathrm{mg} / \mathrm{kg}$ body weight) and five daily intravenous injections of cystosine arabinoside ( $2 \mathrm{mg} / \mathrm{kg} / \mathrm{day}$ ), was begun. She was also given a combination of ampicillin and cloxacillin $250 \mathrm{mg}$ of each drug six-hourly by mouth. Serum electrolytes were estimated daily. On the 12th day in hospital a second course of daunorubicin and cytosine arabinoside was started. Four days later serum electrolytes and blood urea showed the following values: $\mathrm{Na} 128 \mathrm{mEq} / 1$, K $4.6 \mathrm{mEq} / 1$., C1 $98 \mathrm{mEq} / 1$., blood urea, $25 \mathrm{mg} / 100 \mathrm{ml}$. Plasma cortisol and serum T-4 column iodine were within normal limits. The hyponatraemia was associated with the formation of a hypertonic urine (fig. 1). She remained pyrexial. The administration of ampicillin and cloxacillin was discontinued and a combination of gentamicin $(60 \mathrm{mg})$ and carbenicillin (1 g) was given six-hourly by intravenous infusion. The patient complained of a headache and nausea on two occasions during the period of hyponatraemia. The blood urea dropped to $6 \mathrm{mg} / 100 \mathrm{ml}$. Towards the end of the study her fluid intake was restricted and serum $\mathrm{Na}$ rose to $138 \mathrm{mEq} / 1$. (fig. 1).

Case 4.-This 44-year-old man had had frequent night sweats for nine weeks. He was a known diabetic taking chlorpropamide $250 \mathrm{mg}$ daily. His doctor suspected acute leukaemia and initiated corticosteroid therapy (prednisolone $50 \mathrm{mg} /$ day). On admission to hospital he was pale and febrile. Initial investigations showed
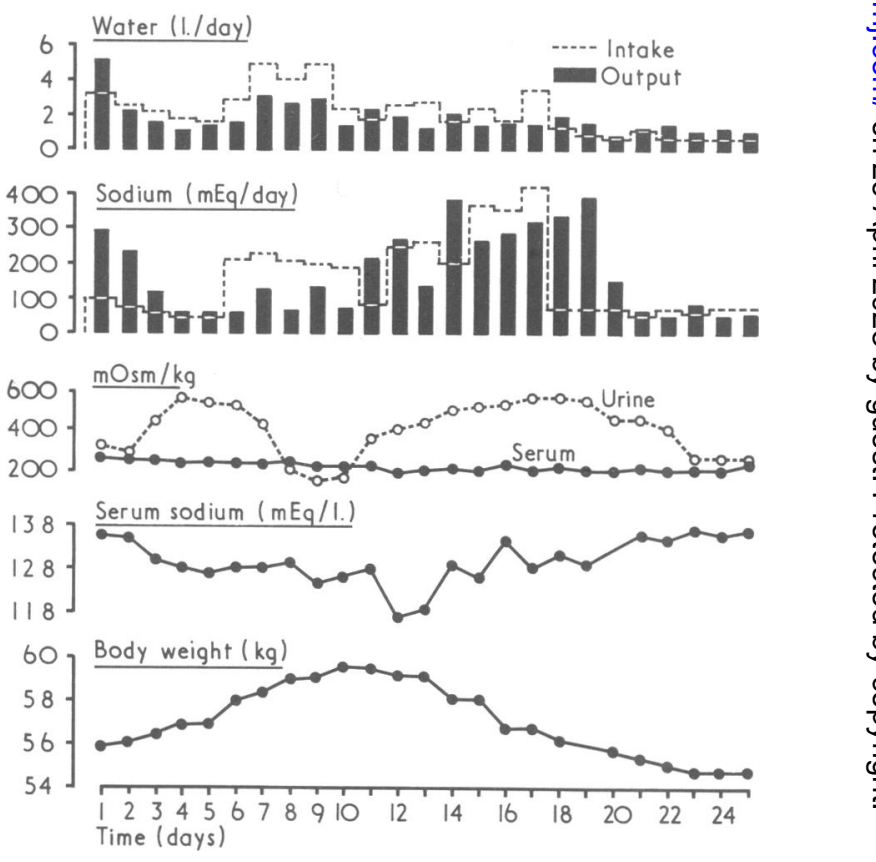

FIG. 1-Case 2. Fluid and sodium balance study 
TABLE I-Haematological Data and Serum Sodium Values in 14 Patients with Acute Leukaemia

\begin{tabular}{|c|c|c|c|c|c|c|c|c|c|}
\hline \multirow{2}{*}{$\begin{array}{l}\text { Case } \\
\text { No. }\end{array}$} & \multirow{2}{*}{$\begin{array}{l}\text { Days after } \\
\text { Diagnosis }\end{array}$} & \multicolumn{2}{|c|}{ Blast Cell Count } & \multirow{2}{*}{\multicolumn{2}{|c|}{$\underset{(\mathrm{mEq} / \mathrm{l} .)}{\text { Serum } \mathrm{Na}}$}} & \multirow{2}{*}{$\begin{array}{c}\text { Diagnosis } \\
\text { (Acute Leukaemia) }\end{array}$} & \multirow{2}{*}{\multicolumn{2}{|c|}{$\begin{array}{l}\text { Cytotoxic Therapy } \\
\text { (No. of Courses*) }\end{array}$}} & \multirow[b]{2}{*}{ Other Treatment } \\
\hline & & Bone Marrow & $\begin{array}{l}\text { Peripheral Blood } \\
\text { Absolute }\left(\times 10^{3}\right)\end{array}$ & & & & & & \\
\hline $\begin{array}{r}1 \\
2 \\
3 \\
4 \\
5 \\
6 \\
7 \\
8 \\
9 \\
10 \\
11 \\
12 \\
13 \\
14\end{array}$ & $\begin{array}{r}2 \\
36 \\
6 \\
21 \\
4 \\
55 \\
1 \\
4 \\
2 \\
15 \\
5 \\
56 \\
1 \\
19 \\
7 \\
11 \\
6 \\
13 \\
2 \\
4 \\
10 \\
17 \\
2 \\
13 \\
4 \\
26 \\
5 \\
42\end{array}$ & $\begin{array}{r}90 \\
5 \\
95 \\
40 \\
70 \\
10 \\
90 \\
75 \\
90 \\
30 \\
70 \\
15 \\
80 \\
20 \\
80 \\
? \\
59 \\
45 \\
72 \\
? \\
80 \\
10 \\
90 \\
50 \\
90 \\
30 \\
90 \\
15\end{array}$ & $\begin{array}{r}0 \cdot 28 \\
0 \cdot 07 \\
0 \cdot 42 \\
0 \cdot 05 \\
5 \cdot 40 \\
0 \cdot 96 \\
141 \cdot 81 \\
120 \cdot 54 \\
14 \cdot 20 \\
\text { None } \\
0 \cdot 88 \\
0 \cdot 02 \\
0 \cdot 40 \\
\text { None } \\
34 \cdot 20 \\
3 \cdot 00 \\
5 \cdot 10 \\
0 \cdot 05 \\
45 \cdot 50 \\
67 \cdot 60 \\
0 \cdot 19 \\
\text { None } \\
45 \cdot 60 \\
\text { None } \\
23 \cdot 80 \\
12 \cdot 60 \\
0 \cdot 40 \\
0 \cdot 48\end{array}$ & $\begin{array}{l}140 \\
126 \\
141 \\
128 \\
141 \\
137 \\
132 \\
129 \\
139 \\
133 \\
139 \\
126 \\
137 \\
127 \\
140 \\
133 \\
136 \\
134 \\
135 \\
132 \\
141 \\
137 \\
133 \\
134 \\
138 \\
133 \\
144 \\
136\end{array}$ & $\zeta$ & $\begin{array}{c}\text { Myeloblastic } \\
\text { Myeloblastic } \\
\text { Myeloblastic } \\
\text { Myelomonocytic } \\
\text { Myelomonocytic } \\
\text { Myeloblastic } \\
\text { Myeloblastic } \\
\text { Myeloblastic } \\
\text { Myeloblastic } \\
\text { Myeloblastic } \\
\text { Myeloblastic } \\
\text { Myeloblastic } \\
\text { Myelomonocytic } \\
\text { Myeloblastic }\end{array}$ & $\begin{array}{c}\text { None } \\
3 \\
\text { None } \\
\text { 2nd course } \\
\text { None } \\
4 \\
\text { None } \\
\text { None } \\
\text { None } \\
1 \\
\text { None } \\
3 \\
\text { None } \\
2 \\
\text { None } \\
1 \\
\text { None } \\
1 \\
\text { None } \\
\text { None } \\
\text { None } \\
1 \\
\text { None } \\
1 \\
\text { None } \\
1 \\
\text { None } \\
3\end{array}$ & $\begin{array}{l}\{ \\
\{ \\
\{ \\
\{ \\
\{ \\
\{ \\
\{ \\
\{\end{array}$ & 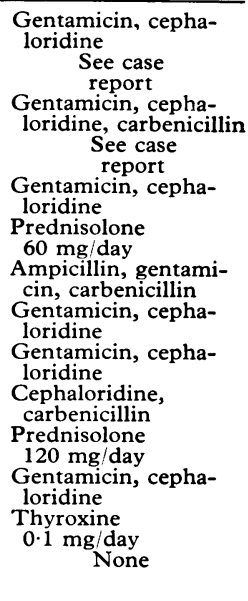 \\
\hline
\end{tabular}

* One course $=\mathrm{A}$ single intravenous administration of daunorubioin and five daily injections of cytosine arabinoside.

normal values for plasma proteins, serum iron, immunoglobulins, and for hepatic function studies. Routine urine analysis showed glycosuria, and the blood sugar was $120 \mathrm{mg} / 100 \mathrm{ml}$. The haemoglobin was $9.1 \mathrm{~g} / 100 \mathrm{ml}$, platelets $50,000 / \mathrm{mm}^{3}$ and W.B.C. $163,000 / \mathrm{mm}^{3}(87 \%$ myeloblasts and monocytoid blast cells). The serum $\mathrm{Na}$ was $132 \mathrm{mEq} / 1$, , serum K $3.5 \mathrm{mEq} / 1$., C1 $90 \mathrm{mEq} / 1$, and blood urea was $42 \mathrm{mg} / 100 \mathrm{ml}$. The diagnosis of acute myelomonocytic leukaemia was confirmed by a bone marrow examination. It was decided to tail off prednisolone and begin antibiotic and cytotoxic therapy. Gentamicin ( $80 \mathrm{mg}$ eight-hourly) and cephaloridine ( $500 \mathrm{mg}$ six-hourly) were administered by intravenous infusion. The serum $\mathrm{Na}$ level fell to $129 \mathrm{mEq} / \mathrm{l}$. before starting the cytotoxic therapy. There was no clinical or laboratory evidence of adrenal, thyroid, hepatic, or renal insufficiency. A five-day induction course of cytotoxic therapy was initiated. Prednisolone and chlorpropamide were discontinued and the diabetic state was adequately controlled with soluble insulin 20 units twice a day.

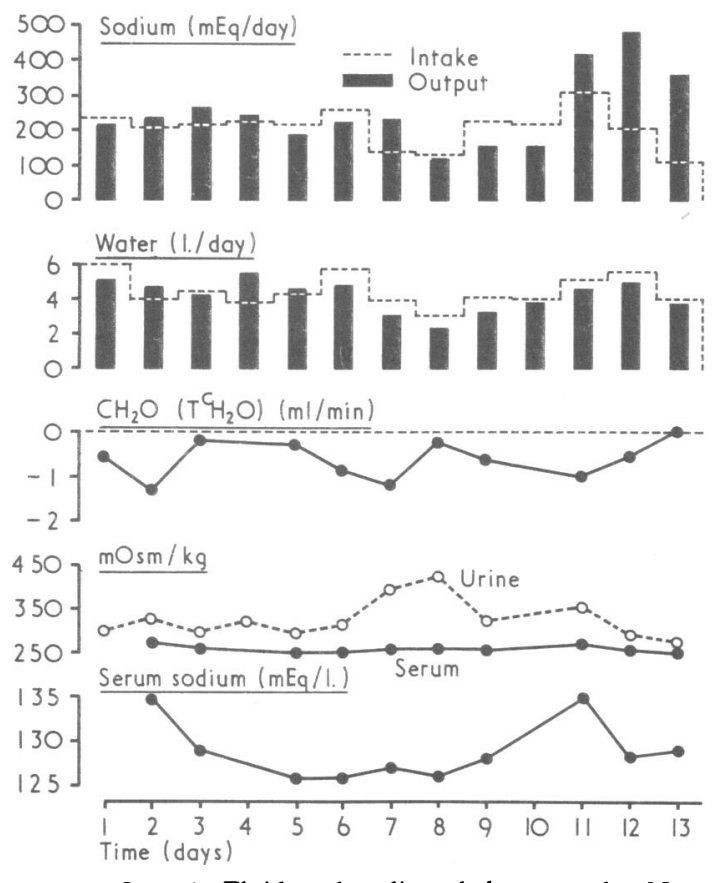

FIG. 2-Case 4. Fluid and sodium balance study. Note negative free water clearance (tubular clearance of water) throughout period of study.
The hyponatraemia continued throughout the period of the study (fig. 2) despite the withdrawal of chlorpropamide. The blood urea dropped to $12 \mathrm{mg} / 100 \mathrm{ml}$. He was discharged 17 days after admission. He was readmitted on two more occasions and found to have a low serum $\mathrm{Na}$ concentration which returned to normal on each occasion when his oral intake of fluids was restricted to less than 2 l./day.

\section{Results}

Hyponatraemia (serum $\mathrm{Na}<135 \mathrm{mEq} / \mathrm{l}$.) developed in 11 of the 14 patients $(78 \%$ ). Three of these 11 patients (cases 4,10 , and 12) had a low serum $\mathrm{Na}$ level on admission before any cytotoxic therapy had been initiated (table I). One (case 4) was taking chlorpropamide and prednisolone (see Case Report) but the other two patients had not received drugs before the development of hyponatraemia. Two other patients (cases 7 and 9) had serum $\mathrm{Na}$ levels in the lower range of normal (table I) before any treatment had been started, and these levels dropped further after induction therapy. Four of these five patients had a high absolute blast cell count. The remaining six patients developed hyponatraemia after antileukaemic therapy. In each of these six cases a considerable fall in the blast cell count (bone marrow and peripheral blood) coincided with a fall in the serum $\mathrm{Na}$ level (table I). Some reduction in the serum $\mathrm{Na}$ level was

TABLE II-Sodium Balance, Urinary, and Serum Osmolality Values in 14 Patients with Acute Leukaemia

\begin{tabular}{|c|c|c|c|c|c|}
\hline \multirow[t]{2}{*}{ Case No. } & \multicolumn{2}{|c|}{$\begin{array}{l}\text { Osmolality* } \\
(\mathrm{m} 0 \mathrm{sm} / \mathrm{kg})\end{array}$} & \multirow[t]{2}{*}{$\begin{array}{l}\text { Na Intake } \\
\text { (mEq/day) }\end{array}$} & \multicolumn{2}{|c|}{$\begin{array}{l}\text { Urinary } \mathrm{Na} \\
\text { (mEq/day) }\end{array}$} \\
\hline & Serum & Urine & & $\begin{array}{c}\text { Before } \\
\text { Therapy } \dagger\end{array}$ & $\underset{\text { Therapy }}{\text { During }}$ \\
\hline $\begin{array}{r}1 \\
2 \\
3 \\
4 \\
5 \\
6 \\
7 \\
8 \\
9 \\
10 \\
11 \\
12 \\
13 \\
14\end{array}$ & $\begin{array}{l}264 \\
255 \\
274 \\
260 \\
286 \\
268 \\
258 \\
254 \\
274 \\
284 \\
276 \\
272 \\
270 \\
276\end{array}$ & $\begin{array}{l}680 \\
460 \\
412 \\
416 \\
384 \\
647 \\
429 \\
422 \\
490 \\
364 \\
432 \\
540 \\
421 \\
?\end{array}$ & $\begin{array}{c}65-75 \\
52-100 \\
65-78 \\
120-256 \\
145-230 \\
72-140 \\
74-140 \\
70-140 \\
68-220 \\
220-405 \\
60-95 \\
65-130 \\
65-110 \\
68-75\end{array}$ & $\begin{array}{r}56 \\
65 \\
? \\
204 \\
5 \\
186 \\
20 \\
? \\
2 \\
18-94 \\
295 \\
19 \\
84 \\
?\end{array}$ & $\begin{array}{r}22-99 \\
55-280 \\
92-150 \\
157-485 \\
95-133 \\
126-324 \\
45-138 \\
124-319 \\
91-176 \\
194-495 \\
72-221 \\
59-153 \\
123-301 \\
105-136\end{array}$ \\
\hline
\end{tabular}

*At onset of hypotraemia tCytosine arabinoside and daunorubicin. 
seen to occur in association with a fall in the blast cell count in all patients who received cytotoxic therapy.

Sodium Balance Studies.-Patients were allowed a sodium intake of $60-85 \mathrm{~m} \mathrm{Eq} /$ day. Variations in either direction occurred as a result of poor appetite and intravenous therapy. Pretreatment urine collection was incomplete in three patients but urinary $\mathrm{Na}$ values were obtained in the other 11 before induction therapy (table II). Seven of these patients were in positive $\mathrm{Na}$ balance but their urinary sodium excretion increased appreciably during induction therapy. The pretreatment urinary excretion of $\mathrm{Na}$ was high in three patients and this remained raised during antileukaemic therapy (table II). It is noteworthy that these three patients with a significant natriuresis were on high doses of prednisolone (table I). An increase in salt intake led to a further loss of $\mathrm{Na}$ in urine in all the 14 patients (table II) without any significant improvement in the serum $\mathrm{Na}$ level (see figs. 1 and 2).

Urine and Serum Osmolality.-The urine was found to be consistently hypertonic to the serum at the onset of hyponatraemia in all the 11 patients (table II).

Effects of Variation in Fluid and Sodium Intake.-Two patients (cases 2 and 4 ) were investigated in some depth in order to study the effects of alteration of salt and fluid intake. Both were febrile throughout the period of the study and were allowed free access to fluids. One (case 4) drank copiously and his intake, including intravenous fluids, ranged between 4 and 61 ./day. A severe reduction to below $2 \mathrm{l}$./day corrected hyponatraemia on two occasions. The other patient maintained a fluid intake of from 2 to 31 ./day. Her water intake was reduced to $800 \mathrm{ml} / 24 \mathrm{hr}$ on the 19th day of the study. This led to a fall in the urinary output and the serum $\mathrm{Na}$ increased to $137 \mathrm{mEq} / \mathrm{l}$. (fig. 1). The saline load was increased on days 6 to 9 in case 2 . Diuresis ensued with a fall in the urine osmolality (fig. 1). The body weight increased by $2 \mathrm{~kg}$. Sodium intake was increased on days 12 and 17. This aggravated the salt loss in the urine and the serum $\mathrm{Na}$ level fell to its lowest level of $118 \mathrm{mEq} / 1$. on day 12 . Similar results were obtained in case 4 . The increased $\mathrm{Na}$ intake was promptly passed in the urine giving an overall negative $\mathrm{Na}$ balance (fig. 2). The first step in the chain of events in these two patients was an increase in the urinary $\mathrm{Na}$ excretion, and this increased further after an increased salt intake with only a transient improvement in the serum $\mathrm{Na}$ level. Both patients failed to excrete osmoticallyfree water and elaborated urine inappropriately hypertonic to the serum. A severe restriction in the fluid intake led to an increase in the serum $\mathrm{Na}$ level.

Other Studies.-The plasma arginine vasopressin level was found to range between 0.7 and $1.8 \mathrm{pg} / \mathrm{ml}$ in three patients (cases 1,2, and 12) at the height of their hyponatraemia. These values are considered to be at the lower limit of the normal range. (C. G. Beardwell, personal communication, 1973). Plasma cortisol was determined at 10 a.m. on two consecutive days in 11 patients and the average of the two values is shown in table III. There was no adrenal or thyroid insufficiency as determined by plasma cortisol and T-4 column iodine levels (table III). One patient (case 13) was on L-thyroxine because of previously diagnosed hypothyroidism, but this appeared to be

TABLE III-Creatinine Clearance, Plasma Cortisol, and Serum T-4 Column Iodine Levels in 11 Patients with Hyponatraemia

\begin{tabular}{c|c|c|c}
\hline Case No. & $\begin{array}{c}\text { T-4 Column Iodine } \\
\text { (ug/100 ml) }\end{array}$ & $\begin{array}{c}\text { Plasma Cortisol } \\
\text { (ug/100 ml) }\end{array}$ & $\begin{array}{c}\text { Creatinine Clearance } \\
\text { (ml/min) }\end{array}$ \\
\cline { 1 - 3 } 1 & $3 \cdot 3$ & 23 & 85 \\
2 & $3 \cdot 3$ & $20 \cdot 5$ & 100 \\
4 & $4 \cdot 2$ & 15 & 110 \\
5 & $3 \cdot 6$ & $11 \cdot 5$ & 85 \\
6 & $4 \cdot 7$ & $13 \cdot 5$ & 100 \\
7 & $3 \cdot 6$ & $12 \cdot 6$ & 77 \\
8 & $4 \cdot 5$ & $16 \cdot 5$ & 132 \\
9 & $4 \cdot 6$ & $11 \cdot 5$ & 116 \\
10 & $4 \cdot 9$ & 19 & 162 \\
12 & $6 \cdot 1$ & & \\
13 & & $10-30$ & $75-130$ \\
\hline Normal & & & \\
range (6 & $2 \cdot 3-6 \cdot 1$ & & \\
subjects) & & &
\end{tabular}

well controlled with treatment and the patient showed no clinical or laboratory evidence of thyroid deficiency. Renal function as determined by creatinine clearance estimations, urine analysis, and blood urea levels was found to be adequate at the onset of hyponatraemia in all patients. Blood urea levels fell with the development of hyponatraemia in all patients and values below $15 \mathrm{mg} / 100 \mathrm{ml}$ were observed in four patients (cases 1-4).

\section{Discussion}

The low serum Na state did not appear to be related to therapy in two patients (cases 10 and 12) who developed hyponatraemia before any treatment had been started (table I). One patient (case 4) had been on chlorpropamide and prednisolone before the development of hyponatraemia. Chlorpropamide therapy has been found to induce fluid retention and hyponatraemia but the syndrome abates after withdrawal of the drug (Fine and Shedrovilzky, 1970, Weissman et al., 1971). Hyponatraemia persisted in case 4 despite the cessation of chlorpropamide therapy.

The patients reported on here presented a syndrome characterized by natriuresis, hyponatraemia, and failure to excrete osmotically-free water. These features resemble those associated with inappropriate secretion of antidiuretic hormone. This syndrome was first described by Schwartz et al. (1957) in two patients with bronchogenic carcinoma. Awareness of this association has brought to light a wide variety of conditions in which an abnormally sustained secretion of antiduiretic hormone has been invoked to explain hyponatraemia (Bartter and Schwartz, 1967). Though reported to occur in Hodgkin's disease (Spittle, 1966), so far as we are aware acute leukaemia has not been known to be associated with this syndrome.

It appears unlikely that the low serum $\mathrm{Na}$ state in these patients was due to an excess of antidiuretic hormone since plasma arginine vasopressin levels were found to be normal in three patients with the syndrome. The data available here favour the conclusion that this syndrome of hyponatraemia was induced by a natriuretic substance which was not antidiuretic hormone but resembled it in most of its actions. The most prominent feature in seven of the 11 patients was an increase of natriuresis after the administration of cytotoxic therapy with a consequent fall in the serum Na level (tables I and II). The three patients excreting large quantities of $\mathrm{Na}$ before induction therapy were taking high doses of prednisolone. It was a paradoxical phenomenon since corticosteroids are well known for their saltretaining effect (Lange and Doorenbos, 1972). Occasionally hypernatraemia has been observed to develop after the administration of pharmacological doses of corticosteroids (Sawyer et al., 1967). It is possible that this phenomenon of natriuresis associated with the administration of prednisolone in these three patients may have had the same basis as the augmented natriuresis induced by cytotoxic therapy in the other seven patients. Corticosteroids have non-specific antileukaemic properties and have been reported to induce remission in a significant proportion of patients with acute leukaemia (Fessas et al., 1954; Sampey, 1963). It would seem reasonable to postulate that this syndrome of hyponatraemia may be caused by a natriuretic substance released from leukaemic cells. This substance may have been released as a result of wear and tear during a high turnover of blast cells in four patients with a high absolute blast cell count who had hyponatraemia before antileukaemic therapy.

The concept that primitive cells of the myeloid series secrete a natriuretic substance is not an exaggeration of the functional scope of these cells. Leucocytes are thought to produce a significant portion of vitamin $\mathrm{B}_{12}$-binding alphaglobulin (Simons and Weber, 1966), and there is enough evidence to indicate that white blood cells are a source of a low molecular weight protein, lysozyme (Barnes, 1940; Osserman and Lawlor, 1966). However, the conclusion that an antidiuretic-hormonelike substance is released from the white cells is speculative, and further studies are required to prove it.

The presence of this syndrome in a high proportion of patients 
with acute myeloid leukaemia is of great clinical importance. Water intoxication may produce confusion (Kaye, 1966) and disorientation (Weissman et al., 1971)-symptoms which can readily be confused with the terminal state of acute leukaemia. Intravenous infusion can be hazardous in these patients. Attention to the underlying electrolyte imbalance will lead to the correct diagnosis, which is reversible by water restriction.

We appreciate the kind co-operation of Dr. C. G. Beardwell, of the Clinical Research Laboratories, Christie Hospital, and Holt Radium Institute, Withington, Manchester, in performing radioimmunoassay for the determination of plasma arginine vasopressin. Our thanks are due to Dr. J. D. Swales for his helpful criticism.

\section{References}

Barnes, J. M. (1940). British fournal of Experimental Pathology, 21, 264.
Bartter, F. C., and Schwartz, W. B. (1967). American fournal of Medicine, 42, 790.

Beardwell, C. G. (1971). fournal of Clinical Endocrinology, 33, 254.

Fessas, P., Wintrobe, M. M., Thompson, R. B., and Cartwright, G. E. (1954). Archives of Internal Medicine, 94, 384.

Fine, D., and Shedrovilzky, H. (1970). Annals of Internal Medicine, 72, 83. Kaye, M. (1966). American Fournal of Medicine, 41, 910.

Lange, W. E. de, and Doorenbos, H. (1972). In Side Effects of Drugs, ed. L. Meyler, vol. VII, p. 525. Amsterdam, Excerpta Medica.

McCance, R. A., and Widdowson, E. M. (1969). The Composition of Foods, 3rd edn. London, H.M.S.O

Mattingly, D., Dennis, P. M., Pearson, J., and Cope, C. L. (1964). Lancet, 2, 1046. Osserman, E. F., and Lawlor, D. P. (1966). Fournal of Experimental Medicine,

Sampey, J. R. (1963). American fournal of Pharmacy, 135, 380.

Sawyer, R. B., Spencer, J. R., Dudzenski, P. J., and Enis, J. E. (1967). American fournal of Surgery, 114, 691.

Schwartz, W. B., Bennett, W., Corelop, S., and Bartter, F. C. (1957) American fournal of Medicine, 23, 529.

Simons, K., and Weber, T. (1966). Biophysics Acta, 117, 201.

Spittle, M. F. (1966). Postgraduate Medical Fournal, 42, 523.

Weissman, P. N., Shenkman, L., and Gregerman, R. I. (1971). New England fourn,ll of Medicine, 284, 65 .

\title{
Remission of Diabetes Mellitus during Pregnancy
}

\author{
JOANNA SHELDON, TIMOTHY COLEMAN
}

British Medical fournal, 1974, 1, 55-57

\section{Summary}

Two cases are reported in which a remission of diabetes was sustained throughout pregnancy. This seemed to be due in part to improved $\beta$-cell function consequent on restoration of normoglycaemia before pregnancy, and in part to an increase in insulin sensitivity during pregnancy, which in the first case disappeared very rapidly after delivery.

\section{Introduction}

Though partial remission of diabetes is not uncommon in young diabetics soon after control has been established the return to normal glucose tolerance is rare (Harwood, 1957; Peck et al., 1958; Stutman and Hayes, 1959; Hines and Kessler, 1961; Field et al., 1961; Brereton, 1968). For glucose tolerance to remain normal throughout pregnancy in a diabetic is even more remarkable. It seemed of interest, therefore, to report two cases in which remission of diabetes persisted during pregnancy, the response to $50-\mathrm{g}$ oral glucose tolerance tests remaining normal throughout in one and nearly normal in the other.

\section{Case 1}

This patient was found to be a diabetic at the age of 29 when she presented with a three-month history of recurrent boils. There were no other symptoms and she was of normal weight. The blood glucose in the mid-morning at her first clinic visit was $302 \mathrm{mg} / 100$ $\mathrm{ml}$ (G.O.D. period method, Boehringer). After one month on a $150-\mathrm{g}$ carbohydrate diet her mid-morning blood glucose was $334 \mathrm{mg} / 100$ $\mathrm{ml}$. She was therefore given chlorpropamide $250 \mathrm{mg}$ daily (fig. 1). After starting chlorpropamide, and until after delivery, all midmorning blood glucose values were below $120 \mathrm{mg} / 100 \mathrm{ml}$ (mean

\section{Royal Sussex County Hospital, Brighton BN2 5BE}

JOANNA SHELDON, M.D., M.R.C.P. Consultant Physician

TIMOTHY COLEMAN, M.B., B.S., Research Registrar

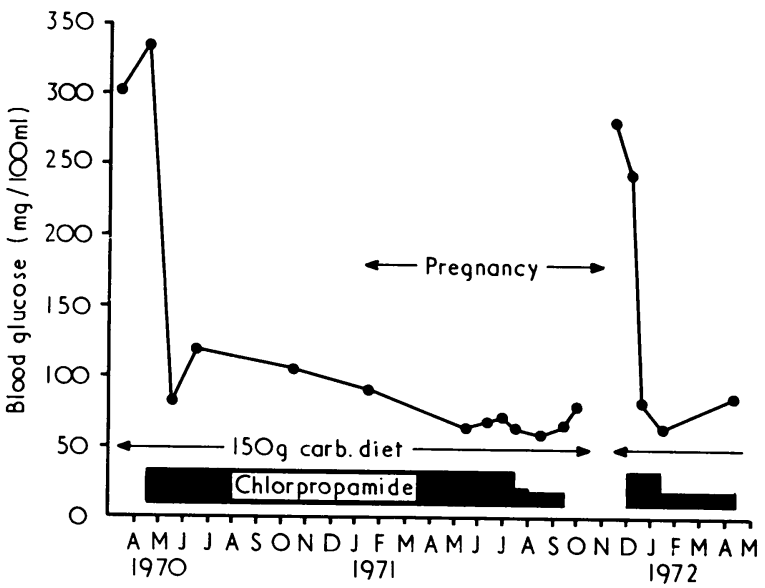

FIG. 1-Case 1. Mid-morning blood glucose values over two-year period. Readings taken two to three hours after a meal.

$83 \mathrm{mg} / 100 \mathrm{ml})$. All urine tests done twice daily throughout pregnancy were negative for sugar. Chlorpropamide was discontinued at 32 weeks of pregnancy. Between the $33 \mathrm{rd}$ and 37 th weeks four 50 -g oral glucose tolerance tests were done (table I). The highest one-hour value was $173 \mathrm{mg} / 100 \mathrm{ml}$ and the highest two-hour value $123 \mathrm{mg} / 100 \mathrm{ml}$. (A $100-\mathrm{g}$ oral glucose tolerance test at 35 weeks, however, produced a two-hour blood glucose of $175 \mathrm{mg} / 100$ $\mathrm{ml}$, and response to a cortisone glucose tolerance test (Fajans and Conn, 1961) was grossly abnormal at 38 weeks). Serum insulin (Hales and Randle, 1963) was low throughout all these tests for this stage of pregnancy. Plasma placental lactogen (Letchworth et al., 1971) estimated during each test was within the normal range (table I). Twenty-four-hour urinary oestriol (Brombacher et al., 1968) measured on 11 occasions from the 32nd week was also normal, ranging from 10.5 to $44.3 \mathrm{mg} / 24$ hours.

Glycosuria reappeared four days after delivery and glucose tolerance deteriorated rapidly thereafter (fig. 2).

The baby, delivered at 38 weeks, was a typical infant of a diabetic mother, weighing $4,360 \mathrm{~g}$ at birth. The placenta was also a little heavy $(51 \mathrm{~g})$. The baby rapidly became hypoglycaemic, cord blood glucose dropping from $88 \mathrm{mg} / 100 \mathrm{ml}$ at birth to less than $10 \mathrm{mg} / 100 \mathrm{ml}$ one hour later, when an intravenous glucose infusion was started. In spite of a continuous glucose infusion and glucagon 